\title{
Effect of probiotics on digestive metabolism in growing and laying poultry birds
}

\author{
V.H. Temiraev'1, A.A. Baeva², L.A. Vityuk ${ }^{2}$, M.N. Mamukaev${ }^{1}$, N.A. \\ Yurina $^{3 \& 4}$, I.I. Ktsoeva ${ }^{1}$, L.A. Bobyleva ${ }^{5}$, E.F. Zagaraeva ${ }^{5}$, T.N. Kokov ${ }^{6}$, \\ F.A. Vologirova ${ }^{6}$
}

${ }^{1}$ Gorsky State Agrarian University, Vladikavkaz, 362040; ${ }^{2}$ North-Caucasian Mining and Metallurgical Institute (State Technological University), Vladikavkaz, 362021; ${ }^{3}$ Krasnodar Research Centre for Animal Husbandry and Veterinary Medicine, Krasnodar 350055; ${ }^{4}$ Kuban State Agrarian University named after I.T. Trubilina, Krasnodar 350044; ${ }^{5}$ North-Ossetian State University named after K.L. Khetagurov, Vladikavkaz, 362025; ${ }^{6}$ KabardinoBalkarian State Agrarian University named after Kokov, Nalchik, 360030, Russian Federation.

Journal of Livestock Science (ISSN online 2277-6214) 11: 33-39

Received on 1/11/2019; Accepted on 15/1/2020

doi. 10.33259/JLivestSci.2020.33-39

\begin{abstract}
The use of probiotics and enzyme preparations in poultry diets to intensify digestive metabolism in the body is a very pressing problem. The aim of the research was to study the effect of enzyme preparations of protosubtilin GZh and celloviridineG20h, as well as the probiotics of bifidumbacterin on the processes of digestive metabolism in growing birds and laying hens. In the course of the studies, it was found that the joint supplementation of the probiotic BifidumSKhZh at the rate of $5 \mathrm{~g}$ per 200 heads, enzyme preparations of protosubtilin GZh at the rate of $300 \mathrm{~g} / \mathrm{t}$ and celloviridineG20h at the rate of $100 \mathrm{~g} / \mathrm{t}$ of the feed allowed the growing birds and laying hens of the 4th experimental group significantly $(\mathrm{P}>0.95)$ exceed their control analogues in the proteolytic, cellulosolytic and amylolytic activity of the contents of the gizzard stomach and duodenum, in digestibility of crude protein, crude fiber, and nitrogen-free extracts (NFE) of the diets, as well as the level of protein digestibility of forages.
\end{abstract}

Key words: broiler chickens; enzyme preparations; probiotic; enzymatic activity; digestibility and nutrient availability. 


\section{Introduction}

Widespread use of local grain ingredients in large quantities increases the amount of fiber, inhibitors of digestive enzymes. Therefore, for poultry it is especially important to enrich the rations with enzyme preparations that break down the shell of plant cells, resulted in the increased access to their nutrients (Temirayev et al., 2009; Kokayeva, 2008). At the same time, the effect of using exogenous enzymes in the feeding of farm animals and poultry depends on a number of factors: on the properties of the enzyme preparation and its dose, on the composition of the diet, age, the breed and the cross, on the conditions of keeping (Land et al., 2005).

In recent decades, probiotics have been included in the complete feed for poultry as a biological stimulator for the growth of egg productivity and metabolism. They have a positive effect on the poultry organism, expressed in activation of the enzymatic system of the gastrointestinal tract, in changing the populations of intestinal microorganisms in a favorable direction, which leads to increased growth rateofgrowing birds and intensification of egg production (Rambaud et al., 2006; Koenen et al., 2002; Irshad, 2006).

Probiotics have a synergistic effect with a wide range of biologically active additives. One of the promising directions in this area is the search for combinations of enzyme preparations and new forms of probiotics, the use of which activates the digestive processes and increases the productivity of the poultry on this basis (Biswas et al., 2013, Yesuf et al., 2017, Sethy et al., 2017, Tsai et al., 2018).

Proceeding from the foregoing, the use of enzyme preparations and bifidumbacterin probiotics in rations of growing birds and laying hens to increase the physiological and biochemical indices of digestive metabolism in their bodies is quite an actual problem (Temirayev et al., 2013; Bayeva, et al., 2013; Chikov et al., 2012).

The present work was undertaken to study the effect of enzyme preparations of protosubtilin GZh and celloviridineG20h, as well as probiotic bifidumbacterin on physiological and biochemical processes of digestive metabolism in growing birds and laying hens.

\section{Material and methods}

In order to achieve the goal, under the conditions of the poultry farm of LLC "Iraf-Agro" of RNO-Alania (Longitude: $44^{\circ} 40^{\prime} 04^{\prime \prime}$ East, Latitude: $43^{\circ} 02^{\prime} 12^{\prime \prime}$ North. Altitude: $671 \mathrm{~m}$ ), scientific and production and two physiological metabolism trials were conducted on the replacement growing chickens and laying hens of the meat cross "Smena-7".

The scientific and production experiment included two stages of research. In the course of the first stage of the experiment, five groups of 200 heads each were formed from one-day-old conditioned chickens by the method of analog groups. The duration of this stage of research on the replacement growing birds was 22-23 weeks, after which the experimental poultry was transferred to the department for laying hens.

During the II stage of the research and production experiment, the studies were carried out on the same flock that was used during the first stage of the experiment, taking into account their survival rate. The duration of this stage was 300 days. During both stages of the scientific and economic experiment, the replacement growing birds and laying hens were floor-managed.

Feeding of the experimental birds in the course of the experiment was carried out in accordance with the detailed standards of feeding poultry, according to the research scheme given in Table 1 . Table 2 shows the compound feeds of growing young and laying hens.

Table 1 - Scheme of scientific and economic experiment

\begin{tabular}{|c|c|}
\hline Group & Feeding features \\
\hline \multicolumn{2}{|r|}{ I stage of scientific and economic experiment on replacement growing birds } \\
\hline Control & Basic diet (BD) \\
\hline 1 trial & BD+ BifidumSKhZh @ 5 g per 200 heads \\
\hline 2 trial & BD + BifidumSKhZh @ 5 doses per 200 heads + protosubtilinGZh @ 300g/t of feed \\
\hline 3trial & BD + BifidumSKhZh @ 5 g per 200 heads +celloviridineG20h @ 100g/t of feed \\
\hline 4 trial & $\begin{array}{l}\mathrm{BD}+\text { BifidumSKhZh @ } 5 \mathrm{~g} \text { per } 200 \text { heads }+ \text { protosubtilinGZh @ 300g/t of feed+ } \\
\text { celloviridineG20h @ 100g/t of feed }\end{array}$ \\
\hline \multicolumn{2}{|r|}{ II stage of scientific and economic experiment on laying hens } \\
\hline Control & Basic diet (BD) \\
\hline 1 trial & BD + BifidumSKhZh @ 5 g per 200 heads \\
\hline 2 trial & BD + BifidumSKhZh @ 5 g per 200 heads + protosubtilinGZh @ 300g/t of feed \\
\hline 3 trial & BD + BifidumSKhZh @ 5 g per 200 heads + celloviridine G20h @ 100g/t of feed \\
\hline 4trial & $\begin{array}{l}\text { BD + BifidumSKhZh @ } 5 \text { g per } 200 \text { heads }+ \text { protosubtilinGZh @300g/t of feed }+ \\
\text { celloviridineG20h @ 100g/t of feed }\end{array}$ \\
\hline
\end{tabular}


Table 2 - Composition and nutritional value of feed for growing young and laying hens

\begin{tabular}{|c|c|c|}
\hline \multirow[b]{2}{*}{ Indicators } & \multicolumn{2}{|c|}{ Bird } \\
\hline & growing young & laying hens \\
\hline \multicolumn{3}{|c|}{ Composition, \%: } \\
\hline Wheat & 30.0 & 27.0 \\
\hline Barley & 20.0 & 25.5 \\
\hline Sunflower meal & 15.0 & 15.0 \\
\hline Corn & 11.0 & 11.5 \\
\hline Peas & 10.5 & 9.0 \\
\hline Fodder yeast & 5.0 & 7.0 \\
\hline Fish meal & 5.5 & 7.4 \\
\hline Herbal flour & 4.0 & 5.0 \\
\hline Bone meal & 2.4 & 3.8 \\
\hline Chalk feed & 1.1 & 6.3 \\
\hline Common salt & 0.4 & 0.5 \\
\hline Premix & 1.0 & 1.0 \\
\hline \multicolumn{3}{|c|}{$100 \mathrm{~g}$ of feed contains: } \\
\hline exchange energy, MJ & 1.093 & 1.111 \\
\hline crude protein, $\mathrm{g}$ & 15.22 & 14.03 \\
\hline crude fat, $\mathrm{g}$ & 2.52 & 2.83 \\
\hline crude fiber, $\mathrm{g}$ & 5.26 & 4.41 \\
\hline calcium, $\mathrm{g}$ & 1.15 & 2.71 \\
\hline phosphorus, $\mathrm{g}$ & 0.73 & 0.74 \\
\hline sodium, $\mathrm{g}$ & 0.23 & 0.30 \\
\hline lysine, $g$ & 0.65 & 0.75 \\
\hline methionine + cystine $g$ & 0.47 & 0.45 \\
\hline linoleic acid, $g$ & 1.11 & 1.2 \\
\hline $\begin{array}{l}\text { For } 1 \mathrm{t} \text { of feed is } \\
\text { added: } \\
\text { lysine, } \mathrm{g} \\
\text { methionine, } \mathrm{g}\end{array}$ & $\begin{array}{l}650 \\
520\end{array}$ & $\begin{array}{l}170 \\
320\end{array}$ \\
\hline
\end{tabular}

Bird feeding was carried out twice a day. Feed preparations were added to the feed by mixing evenly with the help of dispensers.

Bifidum CJ - a lyophilized microbial mass of live antagonistically active bacteria of strain Bifidumbacterium bifidum No. 1 with the addition of sucrose-gelatin medium. One dose of the drug contains 10 million bifidobacteria cells. The preparation is a loose mass (powder) of beige or whitish-gray color with a specific smell of a sweet taste; when dissolved in water forms a slightly opalescent colorless suspension. Bifidumbacterin is produced by the Partner company (Moscow, Russia) packaged in sterile bags of metal-polymer three-layer material of $5 \mathrm{~g}$ each.

Protosubtilin GZh - is a technical bacterial enzyme preparation of the proteolytic complex - contains acidic, neutral and alkaline proteinases, as well as $\alpha$-amylase, $\beta$-glucanase and other enzymes, is able to break down not only proteins, but also carbohydrates, fats and other nutrients of diets. The drug is obtained by drying on a spray dryer the culture fluid of a strain of Bacillus subtillis grown in a deep way. Protosubtilin GXx includes a large number of peptidases, therefore its spectrum of action is much wider than that of pepsin, trypsin and chymotrypsin combined. Standard proteolytic activity is 7 units / $\mathrm{g}$ (GOST 23636-79). The optimal conditions for the action of the drug are $\mathrm{pH} 7.5-8.5$, temperature 40-500C.

Celloveridin G20x - is an enzyme preparation that has $\beta$-glucose and xylase activities, which allows hydrolysis of $\beta$-glucan and pentosan in feeds composed of wheat and barley. It is a carbohydrate preparation obtained by deep fermentation of a strain of Humicola insolens. In the JVB system (International Biochemical Union), both of the above activities are classified as: endo-1,4- $\beta$-glucanase (No. 3.2.1.4.) Also has other carbohydrase activities, including $\beta$-glucazidase, hemicellulase and cellulase. The drug has the following types of enzymatic activity (CT): fungal xinase - $800 \mathrm{FXV} / \mathrm{g}$; pentosanase - $2500 \mathrm{PTV} / \mathrm{g}$; fungal $\beta$-glucanase - 75 FBJ / g; endo- $\beta$-glucanase - $120 \mathrm{EJV} / \mathrm{g}$. The manufacturer of two enzyme preparations is NutriMax (Moscow, Russia).

To determine the digestibility and availability of feed nutrients, 2 physiological experiments were conducted on replacementgrowing birds aged 90-105 days and laying hens - at the age of 350-365 days using an inert chromium oxide indicator (Fomin. Avrutina, 1967).

The enzymatic activity of the contents of the gizzard stomach and duodenum was determined by conventional methods after slaughter of the chickens at the age of 150 days and layers at the age of 450 days (Gil'manov et al., 1981). 
The results of the studies were processed using the Student's method of Variational Statistics using the Microsoft Excel software analysis package.

\section{Results and discussion}

According to the recommendations of the manufacturers, the tested multi-enzyme complexes should be included in the composition of the complete feed, where wheat and barley account for more than $40 \%$ and sunflower meal - up to $15 \%$.

The replacement growing birds and the parent flock of the compared groups were fed with dry complete feed, which included bifidumbacterin and enzyme preparations in a stepwise manner with the help of the metering feeder, so that the biologically active additives were more evenly mixed with the feed.

Special features of the digestive system structure: the presence of a crop and a two-chamber stomach (gizzard and glandular), where generally, there is protein degradation along with the small intestine, have an impact on the fermentation processes of the diet nutrients in the body of poultry. Taking it into account, we studied the enzymatic activity of the contents of the gizzard stomach and duodenum in replacement growing birds and laying hens (Table 3).

In the course of scientific and economic experiment it was found that the mixture of enzymatic preparations of protosubtilinGZh and celloviridineG20h in combination with the probiotic of Bifidum SKhZh had a higher stimulating effect on the synthesis of proteolytic enzymes in the gastrointestinal tract of the replacement growing birds and laying hens. Due to this, the bird of the 4 experimental group had the highest indices of proteolytic activity in the contents of the gizzard stomach and chyme in the duodenum, significantly $(\mathrm{P}>0.95)$ outperforming the control analogues at the first stage of the experiment by 11.2 and $7.7 \%$ and second stage - by 4.7 and $4.8 \%$ respectively.

Table 3 - Dynamics of the enzymatic activity in the contents of gizzard stomach and chyme of duodenum in the test bird, units /g

\begin{tabular}{|c|c|c|c|c|}
\hline \multirow{4}{*}{ Group } & \multicolumn{2}{|c|}{ Gizzardstomach } & \multicolumn{2}{|c|}{ Duodenum } \\
\hline & $\begin{array}{l}\text { replacement } \\
\text { growing birds }\end{array}$ & laying hens & $\begin{array}{l}\text { replacement } \\
\text { growing birds }\end{array}$ & Laying hens \\
\hline & age, days & age, days & age, days & age, days \\
\hline & 150 & 455 & 150 & 455 \\
\hline \multicolumn{5}{|c|}{ Proteolytic activity, units/g } \\
\hline Control & $43.5 \pm 0.16$ & $50.9 \pm 0.25$ & $130.4 \pm 0.24$ & $148.5 \pm 0.29$ \\
\hline 1 trial & $46.1 \pm 0.20^{*}$ & $52.8 \pm 0.28^{*}$ & $133.0 \pm 0.34 *$ & $152.5 \pm 0.38 *$ \\
\hline 2 trial & $46.3 \pm 0.26^{*}$ & $53.4 \pm 0.30 *$ & $134.0 \pm 0.27 *$ & $153.2 \pm 0.33^{*}$ \\
\hline 3 trial & $47.4 \pm 0.15^{*}$ & $53.7 \pm 0.23^{*}$ & $134.4 \pm 0.33 *$ & $154.0 \pm 0.36^{*}$ \\
\hline 4 trial & $48.4 \pm 0.21 *$ & $54.8 \pm 0.33^{*}$ & $136.6 \pm 0.39 *$ & $155.6 \pm 0.41 *$ \\
\hline \multicolumn{5}{|c|}{ Celluloseolytic activity, units/g } \\
\hline Control & $13.5 \pm 0.12$ & $16.9 \pm 0.22$ & $20.4 \pm 0.22$ & $22.5 \pm 0.21$ \\
\hline 1 trial & $15.1 \pm 0.22 *$ & $18.3 \pm 0.20 *$ & $21.7 \pm 0.14 *$ & $23.6 \pm 0.18^{*}$ \\
\hline 2 trial & $15.3 \pm 0.20 *$ & $18.4 \pm 0.23^{*}$ & $21.9 \pm 0.17 *$ & $23.8 \pm 0.23 *$ \\
\hline 3 trial & $15.5 \pm 0.18^{*}$ & $18.7 \pm 0.18^{*}$ & $22.1 \pm 0.23 *$ & $24.0 \pm 0.26^{*}$ \\
\hline 4 trial & $16.2 \pm 0.27 *$ & $19.3 \pm 0.30 *$ & $22.8 \pm 0.19 *$ & $24.6 \pm 0.31 *$ \\
\hline \multicolumn{5}{|c|}{ Lipolytic activity, units/g } \\
\hline Control & $16.89 \pm 0.24$ & $18.65 \pm 0.24$ & $72.73 \pm 0.23$ & $76.87 \pm 0.20$ \\
\hline 1 trial & $16.95 \pm 0.35$ & $18.82 \pm 0.26$ & $72.86 \pm 0.31$ & $76.44 \pm 0.26$ \\
\hline 2 trial & $17.03 \pm 0.29$ & $18.94 \pm 0.28$ & $73.00 \pm 0.36$ & $77.05 \pm 0.28$ \\
\hline 3 trial & $16.44 \pm 0.28$ & $18.76 \pm 0.23$ & $72.71 \pm 0.23$ & $76.73 \pm 0.30$ \\
\hline 4 trial & $17.31 \pm 0.32$ & $19.11 \pm 0.30$ & $73.10 \pm 0.34$ & $77.01 \pm 0.27$ \\
\hline \multicolumn{5}{|c|}{ Amylolytic activity, units/g } \\
\hline Control & $84.2 \pm 0.17$ & $91.0 \pm 0.26$ & $272.1 \pm 0.26$ & $296.2 \pm 0.29$ \\
\hline 1 trial & $88.6 \pm 0.20 *$ & $96.6 \pm 0.21^{*}$ & $295.2 \pm 0.32 *$ & $316.6 \pm 0.38 *$ \\
\hline 2 trial & $89.3 \pm 0.25 *$ & $97.2 \pm 0.25^{*}$ & $295.5 \pm 0.37 *$ & $316.2 \pm 0.33^{*}$ \\
\hline 3 trial & $89.6 \pm 0.28 *$ & $97.6 \pm 0.23 *$ & $296.0 \pm 0.43 *$ & $316.6 \pm 0.36 *$ \\
\hline 4 trial & $90.3 \pm 0.23 *$ & $98.3 \pm 0.33^{*}$ & $297.1 \pm 0.39 *$ & $319.4 \pm 0.39 *$ \\
\hline
\end{tabular}

With the age of the bird, during the experiment, we found a tendency of increasing the proteolytic activity of the contents of the studied sections of the gastrointestinal tract, which corresponds to the general biological regularities of the formation of the digestive system in poultry. 
It has been found that the feeding of the probiotic alone or in combination with protosubtilin GZh and celloviridinG20h because of the absence of lipases in the composition of the used enzyme preparations did not actually affect the lipolytic activity of the contents of the gizzard stomach and duodenal chyme of the test bird, since there were no significant differences $(\mathrm{P}<0.95)$ between the analogs of the control and experimental groups in all age periods.

It is known that poultry has a weak development of cellulolytic microflora of the gastrointestinal tract, with the exception of the caecum. However, bifidobacteria are able to secrete $\beta$-glucanases, and in addition, the supply of exogenous cellulolytic enzymes in the rations of the birdsof the 4 experimental group contributed to a significant ( $P>0.95$ ) increase in cellulases activity in the contents of the gizzard and duodenum by 20.000 and $14.2 \%$ in growing birds and in laying hens - by 11.8 and $9.3 \%$ respectively.

The processes of glycolysis in the body of the poultry are inseparably linked with the transformation of nitrogenous substances, since carbohydrates act as the main source of energy accumulated in the macroergic bonds of ATP and used for protein synthesis in organs and tissues.

Along with this, it was found that the additives of the bifidumbacterin probiotic and a mixture of multienzyme complexes of protosubtilinGZh and celloviridineG20h enabled the replacement growing birds and laying hens of the 4 experimental group significantly $(\mathrm{P}>0.95)$ exceed their control analogues for amylolytic activity of the contents of the gizzard stomach by 7.2 and $8.0 \%$, as well as the duodenum - by 9.2 and $7.8 \%$, respectively.

Due to the synergism of the amylases effect, secreted by bifidobacteria, and amylolytic enzymes in the composition of enzyme preparations, in the contents of the gizzard stomach and duodenum of the growing birds and laying hens of the $4^{\text {th }}$ experimental group, the activity of amylases was the highest in all studies in comparison with the control analogues.

Consequently, additions of probiotic bifidumbacterin and a mixture of multienzyme complexes of protosubtilinGZh and celloviridineG20hin mixed fodders based on wheat, barley and sunflower oil meal have a positive effect on the biochemical processes of fermentation of feed nutrients in the gastrointestinal tract of replacement growing birds and laying hens.

Based on the results of physiological metabolism trials, the digestibility coefficients of nutrients in rations for the replacement growing birds and laying hens of the compared groups were calculated (Table 4).

In the course of the first physiological trial, the broilers of the fourth experimental group, that received the probiotic and a mixture of enzyme preparations of protosubtilin GZh and celloviridinG20h, had the highest digestibility coefficients of nutrients. Due to this, they had a significant $(\mathrm{P}>0.95)$ advantage in digestibility coefficients of dry matter by $4.2 \%$, organic matter - by $4.1 \%$, crude protein - by $4.1 \%$, crude fiber - by $3.9 \%$ and NFE - by $4.0 \%$, as compared to the control.

In the course of the second physiological metabolism trial, the joint feeding of the test preparations was most effective in digesting the nutrients of the rations, which made it possible to increase significantly $(\mathrm{P}>0.95) \%$ the digestibility coefficient of the dry matter by $4.4 \%$, organic matter - by $4.3 \%$, crude protein - by $3.9 \%$, raw fiber - by $2.8 \%$ and NFE - by $4.6 \%$ in the laying hens of the 4 experimental group as compared to the control. This can be explained by the fact that in this combination these preparations in a more optimal amount enrich the digestive tract of the bird with the necessary complex of missing enzymes.

Absence of lipases in the composition of protosubtilin GZh and celloviridinG20h promoted obtaining practically the same level of digestibility of raw fat in birds of the compared groups.

Consequently, joint additions of a mixture of test preparations made it possible to optimize the sequence and degree of hydrolysis and absorption of protein components, fiber and NFE of feeds in replacement growing birds and laying hens.

Based on the results of physiological metabolic trials, a nitrogen balance was calculated for the replacement growing birds and laying hens (Table 5).

According to the results of the first physiological trial, the supplementation of probiotic bifidumbacterin and a mixture of multi-enzyme composition ofprotosubtilinGZh and celloviridineG20h contributed to the better nitrogen assimilation of the diets of wheat-barley-sunflower-type for replacement growing birds, which allowed the birds of the 4 experimental groups to deposit it in the body by $0.175 \mathrm{~g}(\mathrm{P}>0.95)$ more, and also better utilize it from the accepted amount - by $3.13 \%(\mathrm{P}>0.95)$.

The best utilization of feed nitrogen in laying hens was provided by the combined feeding of probiotic bifidumbacterin and enzyme preparations of protosubtilinGZh and celloviridinG20h. Thus, most of the nitrogen was deposited in the body of chickens of the $4^{\text {th }}$ test group - $0.48 \mathrm{~g}$, which is $8.33 \%(\mathrm{P}>0.95)$ higher than in the control.

According to the utilization of nitrogen from the received amount of $53.96 \%$ and $1.39 \mathrm{~g}$ excreted with the egg, the best indices were also for the birds of the 4th test group, significantly $(\mathrm{P}>0.95)$ having outperformed the control analogues by 6.8 and $17.8 \%$ respectively.

Conclusion- A combination of probiotic of BifidumSKhZh at the rate of $5 \mathrm{~g}$ per 200 heads, enzyme preparations of protosubtilin $\mathrm{GZh}$ at the rate of $300 \mathrm{~g} / \mathrm{t}$ and celloviridineG20h at the rate of $100 \mathrm{~g} / \mathrm{t}$ of feed should be included in the rations of cereal-sunflower type for growing birds and laying hens to intensify biochemical processes of fermentation of feed in the gastrointestinal tract and increase the digestibility and nutrient availability. 
Table 4 - Digestibility coefficients of nutrients of rations forthe test bird,\%

\begin{tabular}{|c|c|c|c|c|c|}
\hline \multirow{2}{*}{ Indices } & \multicolumn{5}{|c|}{ Group } \\
\hline & control & 1 trial & 2 trial & 3 trial & 4 trial \\
\hline \multicolumn{6}{|c|}{ I physiological trial on replacement growing birds } \\
\hline Dry matter & $79.8 \pm 0.42$ & $82.2 \pm 0.39 *$ & $82.9 \pm 0.50 *$ & $82.6 \pm 0.44 *$ & $84.0 \pm 0.37 *$ \\
\hline Organicmatter & $81.4 \pm 0.37$ & $83.6 \pm 0.40 *$ & $84.4 \pm 0.50 *$ & $84.0 \pm 0.45^{*}$ & $85.5 \pm 0.47 *$ \\
\hline Crude protein & $83.9 \pm 0.42$ & $86.5 \pm 0.50 *$ & $86.6 \pm 0.52 *$ & $86.9 \pm 0.50 *$ & $88.0 \pm 0.41 *$ \\
\hline FIber & $11.2 \pm 0.38$ & $13.9 \pm 0.52 *$ & $14.2 \pm 0.45^{*}$ & $14.9 \pm 0.51 *$ & $15.1 \pm 0.55^{*}$ \\
\hline Crude fat & $87.0 \pm 0.74$ & $87.4 \pm 0.68$ & $88.1 \pm 0.63$ & $88.3 \pm 0.84$ & $89.3 \pm 1.15$ \\
\hline NFE & $86.7 \pm 0.45$ & $88.7 \pm 0.62 *$ & $89.7 \pm 0.76 *$ & $88.9 \pm 0.65^{*}$ & $90.7 \pm 0.94 *$ \\
\hline \multicolumn{6}{|c|}{ II physiological trial on laying hens } \\
\hline Dry matter & $77.6 \pm 0.61$ & $80.0 \pm 0.51 *$ & $80.3 \pm 0.46^{*}$ & $80.7 \pm 0.55^{*}$ & $82.0 \pm 0.53^{*}$ \\
\hline Organic matter & $78.7 \pm 0.47$ & $81.1 \pm 0.56^{*}$ & $81.2 \pm 0.37 *$ & $81.8 \pm 0.50^{*}$ & $83.0 \pm 0.58^{*}$ \\
\hline Crude protein & $77.0 \pm 0.49$ & $79.4 \pm 0.62 *$ & $79.8 \pm 0.44 *$ & $80.3 \pm 0.32 *$ & $80.9 \pm 0.59^{*}$ \\
\hline Fiber Клетчатка & $15.2 \pm 0.37$ & $17.0 \pm 0.65 *$ & $17.5 \pm 0.35^{*}$ & $17.5 \pm 0.52 *$ & $18.0 \pm 0.48^{*}$ \\
\hline Crude fat & $79.0 \pm 0.39$ & $78.3 \pm 0.68$ & $77.8 \pm 0.59$ & $78.5 \pm 0.62$ & $78.7 \pm 0.77$ \\
\hline NFE & $84.3 \pm 0.63$ & $86.7 \pm 0.36^{*}$ & $86.9 \pm 0.46^{*}$ & $87.4 \pm 0.61 *$ & $88.9 \pm 0.54 *$ \\
\hline
\end{tabular}

$* \mathrm{P}>0.95$

Table 5 - Digestibility of feed nitrogen by the test bird, $g$

$\mathrm{n}=5$

\begin{tabular}{|c|c|c|c|c|c|}
\hline \multirow{2}{*}{ Indices } & \multicolumn{5}{|c|}{ Group } \\
\hline & control & 1 trial & 2 trial & 3 trial & 4 trial \\
\hline \multicolumn{6}{|c|}{ I physiological trial on replacement growing birds } \\
\hline Taken with feed & $3.155 \pm 0.015$ & $3.167 \pm 0.032$ & $2.995 \pm 0.007$ & $3.155 \pm 0.020$ & $3.123 \pm 0.031$ \\
\hline $\begin{array}{l}\text { Excreted: } \\
\text { in dung }\end{array}$ & $1.513 \pm 0.016$ & $1.437 \pm 0.019 *$ & $1.253 \pm 0.006^{*}$ & $1.405 \pm 0.012 *$ & $1.306 \pm 0.014 *$ \\
\hline in feces & $0.508 \pm 0.016$ & $0.426 \pm 0.003 *$ & $0.355 \pm 0.020 *$ & $0.378 \pm 0.002 *$ & $0.408 \pm 0.006^{*}$ \\
\hline in urine & $1.005 \pm 0.031$ & $1.011 \pm 0.026$ & $0.898 \pm 0.013 *$ & $1.027 \pm 0.021 *$ & $0.898 \pm 0.037 *$ \\
\hline Deposited & $1.642 \pm 0.007$ & $1.730 \pm 0.015^{*}$ & $1.742 \pm 0.04 *$ & $1.750 \pm 0.03 *$ & $1.817 \pm 0.018 *$ \\
\hline $\begin{array}{l}\text { Utilized from } \\
\text { taken, \% }\end{array}$ & $52.05 \pm 0.46$ & $54.62 \pm 0.61 *$ & $58.17 \pm 0.42 *$ & $55.47 \pm 0.79 *$ & $58.18 \pm 0.51 *$ \\
\hline \multicolumn{6}{|c|}{ II physiological trial on laying hens } \\
\hline Taken with feed & $3.52 \pm 0.06$ & $3.55 \pm 0.05$ & $3.50 \pm 0.05$ & $3.57 \pm 0.05$ & $3.55 \pm 0.05$ \\
\hline $\begin{array}{l}\text { Excreted: } \\
\text { in dung }\end{array}$ & $1.86 \pm 0.06$ & $1.82 \pm 0.04$ & $1.80 \pm 0.05$ & $1.79 \pm 0.07 *$ & $1.64 \pm 0.07 *$ \\
\hline in egg & $1.18 \pm 0.02$ & $1.25 \pm 0.02 *$ & $1.24 \pm 0.03$ & $1.29 \pm 0.02 *$ & $1.39 \pm 0.02 *$ \\
\hline Deposited & $0.48 \pm 0.08$ & $0.48 \pm 0.04$ & $0.46 \pm 0.03$ & $0.49 \pm 0.05$ & $0.52 \pm 0.04$ \\
\hline $\begin{array}{l}\text { Utilized from } \\
\text { taken, \% }\end{array}$ & $47.16 \pm 0.54$ & $45.98 \pm 0.39 *$ & $48.60 \pm 0.38 *$ & $49.96 \pm 1.36 *$ & $53.96 \pm 1.38 *$ \\
\hline
\end{tabular}

$* \mathrm{P}>0.95$

\section{References}

1). Bayeva, A.A., Vityuk L.A., Abayeva S.K., Buzoyeva L.B., Abayev A.V. 2013 Tovarovednaya otsenka ptich'yego myasa pri narushenii ekologii pitaniya. Izvestiya Gorskogo gosudarstvennogo agrarnogo universiteta. Vladikavkaz 50: 105-110.

2). Biswas, A. Mohan J., Sastry K.V.H. 2010. Effect of vitamin E on production performance and egg quality traits in Indian native Kadaknath hen. Asian-Australasian Journal of Animal Science 23: 9-12.

3). Chikov A., Kononenko S., Pyshmantseva N., Osepchuk D. 2012. Produktivnoye deystviye probiotika na molodnyak kur-nesushek. Kombikorma 2: 96-97.

4). Fomin A.I. Avrutina A.Ya. 1967. Metodika opredeleniya perevarimosti kormov i skorosti prokhozhdeniya pishchi po pishchevaritel'nomu traktu spomoshch'yu okisi khroma. Metodiki nauchnykh issledovaniy po kormleniyu sel'skokhozyaystvennoy ptitsy. pp $21-25$.

5). Gil'manov M.K., Fusov O.V., Frantsev A.P. 1981. Metody ochistki i izucheniye fermentov rasteniy . Izdatel'stvo «Nauka» Kazakhskoy SSR. Alma-Ata. S. 3. 
6). Irshad, A. 2006. Effect of Probiotics on Broilers Performance. International Journal of Poultry Science. 5: 593597.

7). Koenen, M.E. Jeurissen S.H.N., Boersma W.J.A. 2002. Modulation of the immune response by probiotics in chicken. British Journal of Nutrition 88: 120-121.

8). Kokayeva, M.G. 2008. Povysheniye pishchevoy tsennosti myasa broylerov. / Materialy XII vserossiyskoy nauchno-prakticheskoy konferentsii «Agropromyshlennyy kompleks i aktual'nyye problem ekonomiki regionov». - Maykop. S. 200-201.

9). Land M., Rouster-Stevens K., Woods C., Cannon M., Cnota J., Shetty A. 2005. Lactobacillus sepsis assosiated with probiotic therapy. Pediatrics 111: 178-181.

10). Rambaud J.C., Buts J. P., Corthier, G.B. 2006. Flourie Gut microflora. Digestive physiology and pathology Paris: John Libbey Eurotext, 142-154.

11). Sethy K., Swain P., Behera K., Sahoo N., Agrawalla J., Khadanga V., Mahapatra M.R. and Parhi S.S. 2017. Effect of turmeric (Curcuma longa) supplementation on antioxidants and immunity of broiler birds. Journal of Livestock Science (ISSN online 2277-6214) 8: 103-106

12). Temirayev R.B., Bayeva A.A., Kokayeva M.G. 2009. Povysheniye kachestva myasa kur-broylerov. Myasnaya industriya 6: 25-27.

13).Temirayev R.B., Vityuk L.A., Bayeva A.A., Bazayeva L.M., Savkhalova S.CH., Kalagova R.V. 2013. Vliyaniye usloviy pitaniya tsyplyat-broylerov na ikh khozyaystvenno-biologicheskiye kachestva pri riske aflatoksikoza / Izvestiya Gorskogo gosudarstvennogo agrarnogo universiteta, Vladikavkaz 50: 107-110.

14). Tsai H.L., Chang S.C.C., Lin S.J. 2008. Chang Beneficial effects of maternal vitamin E supplementation on the antioxidant system of the neonate chick brain / Asian-Australasian Journal of Animal Science 21: 225-231.

15). Yesuf K.Y., Mersso B.T., Bekele T.E. 2017. Effects of different levels of turmeric, fenugreek and black cumin on carcass characteristics of broiler chicken. Journal of Livestock Science (ISSN online 2277-6214) 8: 1117. 